\title{
IDENTIFIKASI KEMAMPUAN SISWA SMP NEGERI 4 SIANTAN DALAM MENYUSUN KARYA ILMIAH TENTANG PENJERNIHAN AIR UNTUK MENGATASI PERMASALAHAN LINGKUNGAN LOKAL BERBASIS POTENSI DAERAH DI KECAMATAN SIANTAN
}

\author{
Oleh \\ Hamdani $^{1}$, Syamswisna ${ }^{2}$ \\ Pendidikan Fisika ${ }^{1}$ FKIP Universitas Tanjungpura \\ Pendidikan Biologi ${ }^{2}$ FKIP Universitas Tanjungpura \\ Email: hamdani0521@gmail.com \\ (Jl. Prof. Dr. Hadari Nawawi Pontianak, 78124, Hp: 085245608878)
}

\begin{abstract}
ABSTRAK
Kegiatan ini bertujuan untuk mengidentifikasi kemampuan siswa SMP Negeri 4 Siantan dalam menyusun karya ilmiah tentang penjernihan air untuk mengatasi permasalahan lingkungan lokal berbasis potensi daerah di Kecamatan Siantan. Subyek kegiatan ini adalah siswa SMP Negeri 4 Siantan kelas VIII yang terdiri dari 27 siswa yang terbagi menjadi 9 kelompok. Data dikumpulkan menggunakan lembar penilaian kualitas karya ilmiah dan angket tanggapan siswa. Hasil penelitian menunjukkan bahwa karya ilmiah yang dibuat oleh kelompok siswa kelas VIII dalam mengatasi permasalahan lingkungan lokal memiliki rata-rata skor 2.8 dengan persentase $71.3 \%$, dan kriteria yang diperoleh adalah cukup baik. Rata-rata kemampuan siswa dalam membuat karya ilmiah dari 9 indikator sebesar $91.78 \%$.
\end{abstract}

Kata Kunci: kemampuan siswa, permasalahan lingkungan lokal, potensi lokal

\section{ABSTRACT}

The aim of this action is to identify the student's ability SMP Negeri 4 Siantan in desain of scientific papers about purifier water for resolve local environmental problems based on potential in District Siantan. The subjects of this action were students of SMP Negeri 4 Siantan VIII class consisted of 27 students divided into 9 groups. Data were collected through form scientific work quality sheet and

\footnotetext{
${ }^{1}$ Hamdani adalah Dosen Pendidikan Fisika ${ }^{l}$ FKIP Universitas Tanjungpura

${ }^{2}$ Syamswisna adalah dosen Pendidikan Biologi ${ }^{2}$ FKIP Universitas Tanjungpura
} 
responses questionnaire. The results showed that the scientific work created by a group of VIII class students in desain scientific papers about purifier water for resolve local environmental issues based on potential in District Siantan had an average score of 2.8 with percentage of $71.3 \%$, and the criteria obtained are quite good. The average student's ability to desain of scientific work from 9 indicators obtained $91.78 \%$.

Key word:students ability, local environmental problems, local potency.

\section{PENDAHULUAN}

Proses belajar melibatkan pembentukkan makna oleh siswa dari apa yang mereka lakukan, lihat, dan dengar (Pines dan West, 1986). Menurut Fensham (1994), makna yang dibentuk bergantung pada tingkat pengetahuan yang sudah ada pada diri seorang siswa. Sehubungan dengan pandangan konstruktivisme pada proses pembelajaran, Von Glaserfeld (Suparno, 1997) memberikan pernyataan bahwa siswa memang sudah membawa pengetahuan awal dari lingkungan lokal tempat mereka berasal, pengetahuan awal yang mereka punyai tersebut adalah dasar untuk membangun suatu pengetahuan selanjutnya.

Lingkungan lokal yang dimaksud adalah suatu kejadian, peristiwa, permasalahan atau suatu fenomena yang terjadi pada daerah asal siswa. Permasalahan lingkungan lokal yang terjadi di kecamatan Siantan adalah masalah air bersih. meliputi pencemaran lingkungan dan keanekaragaman hayati bisa dijadikan hingga saat ini, bagi masyarakat sekitarnya, pemenuhan kebutuhan air bersih dilakukan dengan membeli dari PDAM dengan harga yang relatif mahal. Namun bagi sekolah masih tetap menggunakan air sumur. Hal yang terjadi adalah banyak ditemukannya peralatan praktikum yang berkarat. Sebagai individu terpelajar siswa dibawah naungan mata pelajaran muatan lokal dan dibimbing oleh guru IPA mempunyai alternatif untuk membuat alat penjernih air berbasis potensi lokal. Potensi lokal yang digunakan adalah biji kelor yang dapat dijumpai di jalan Pontianak-Siantan.

Pengintegrasian lingkungan lokal dengan memanfaatkan potensi daerah di dalam pembelajaran sekolah penting untuk dilakukan. Hal ini bertujuan agar siswa dapat menyadari dan dapatmengamati secara langsung kondisi sekolah yang telah banyak mengalami kerusakan akibat kurang tersedianya air bersih. 
Kesadaran terhadap keadaan lingkungan lokal yang ada di sekitar siswa merupakan pengetahuan awal yang sangat bermanfaat dalam membantu mahasiswa memahami mata pelajaran muatan lokal.

Selain itu, guru juga terbantu untuk memberikan wujud kerja nyata dalam mengatasi permasalahan lingkungan kepada siswanya. Sehingga dapat meningkatkan kecintaan siswa terhadap potensi (budaya) daerahnya dan menimbulkan keinginan untuk terus melestarikannya. Muatan lokal dengan berwawasan potensi lokal memberikan pengaruh terhadap peningkatan pemahaman siswa terhadap lingkungannya (Cobern \& Aikenhead, 1996).

Hasil penelitian mengenai pengintegrasian lingkungan lokal di dalam pembelajaran telah banyak dipublikasikan oleh beberapa peneliti. Menurut Jegede dan Okebukola (Suastra, 2005), dengan memadukan pengetahuan awal siswa dengan pelajaran biologi di ternyata dapat meningkatkan prestasi belajar siswa. Sementara itu, Baker dan Taylor (1995) menyatakan bahwa jika pembelajaran sains tidak memperhatikan budaya siswa, maka konsekuensinya adalah siswa akan menolak atau menerima hanya sebagian dari konsep-konsep sains yang dikembangkan dalam pembelajaran.

\section{METODE PENELITIAN}

Penelitian tentang kemampuan siswa dalam menyusun karya ilmiah tentang penjernihan air untuk mengatasi permasalahan lingkungan lokal berbasis potensi daerah di Kecamatan Siantan ini merupakan penelitian deskriptif. Penelitian deskriptif merupakan suatu penelitian yang meneliti sekelompok manusia, suatu objek, suatu sistem pemikiran ataupun suatu peristiwa pada masa sekarang (Arikunto, 2006). Adapun tujuan dari penelitian deskriptif ini adalah untuk membuat deskripsi, gambaran atau lukisan secara sistematis, faktual dan akurat mengenai fakta-fakta, sifat-sifat serta hubungan antar fenomena yang diselidiki.Prosedur penelitian yang dilakukan mencakup 3 tahapan yaitu tahap persiapan, tahap pelaksanaan, dan tahap analisis data dan penyusunan laporan.

\section{HASIL DAN PEMBAHASAN}

Pengukuran kinerja siswa dalam mengatasi permasalahan air bersih dilakukan dalam 2x pertemuan. Pada Gambar 1 ditampikan kegiatan siswa dalam membuat penjernih air. 

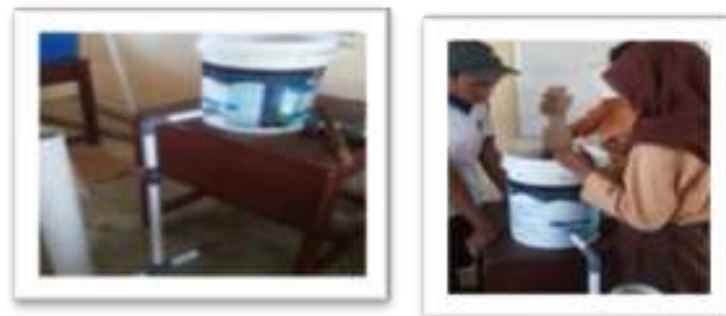

Gambar 1. Proses Pembuatan penjernih air (Dokumentasi pribadi)

Hasil rerata persentase skor kinerja siswa disajikan pada Tabel 1. Kinerja siswa yang diukur meliputi memilih alat/bahan percobaan; menjelaskan langkah/prosedur; kecakapan dalam berkomunikasi; menggunakan alat/bahan percobaan; pengelompokkan data percobaan; mengkomunikasikan hasil percobaan; dan membersihkan alat.

Tabel 1. Persentase dan Kriteria Kinerja Siswa Menyusun Karya Ilmiah

\begin{tabular}{|c|c|c|c|}
\hline \multirow{2}{*}{ Kelompok } & \multicolumn{3}{|c|}{ Kemampuan Siswa } \\
\hline & Rata-rata skor & Persentase (\%) & Kriteria \\
\hline 1 & 3.7 & 92.6 & Sangat Baik \\
\hline 2 & 2.3 & 56.4 & Kurang \\
\hline 3 & 2.8 & 71.3 & Cukup \\
\hline 4 & 1.8 & 45.4 & Kurang Sekali \\
\hline 5 & 2.3 & 56.4 & Kurang \\
\hline 6 & 2.8 & 71.3 & Cukup \\
\hline 7 & 3.7 & 92.6 & Sangat Baik \\
\hline 8 & 2.8 & 71.3 & Cukup \\
\hline 9 & 1.8 & 45.4 & Kurang Sekali \\
\hline Rata-rata & 2.8 & 71.3 & Cukup \\
\hline
\end{tabular}

Skor total yang diperoleh oleh kelompok siswa merupakan penjumlahan dari skor pada setiap kriteria. Skor paling tinggi adalah 4. Skor pada setiap kriteria menggambarkan kinerja siswa dalam proses membuat karya ilmiah. Kemudian skor pada setiap kriteria dirata-ratakan dan dipersentasekan. Data 
tersebut menunjukkan perbedaan kinerja siswa dalam membuat komponen penyusun karya ilmiah.

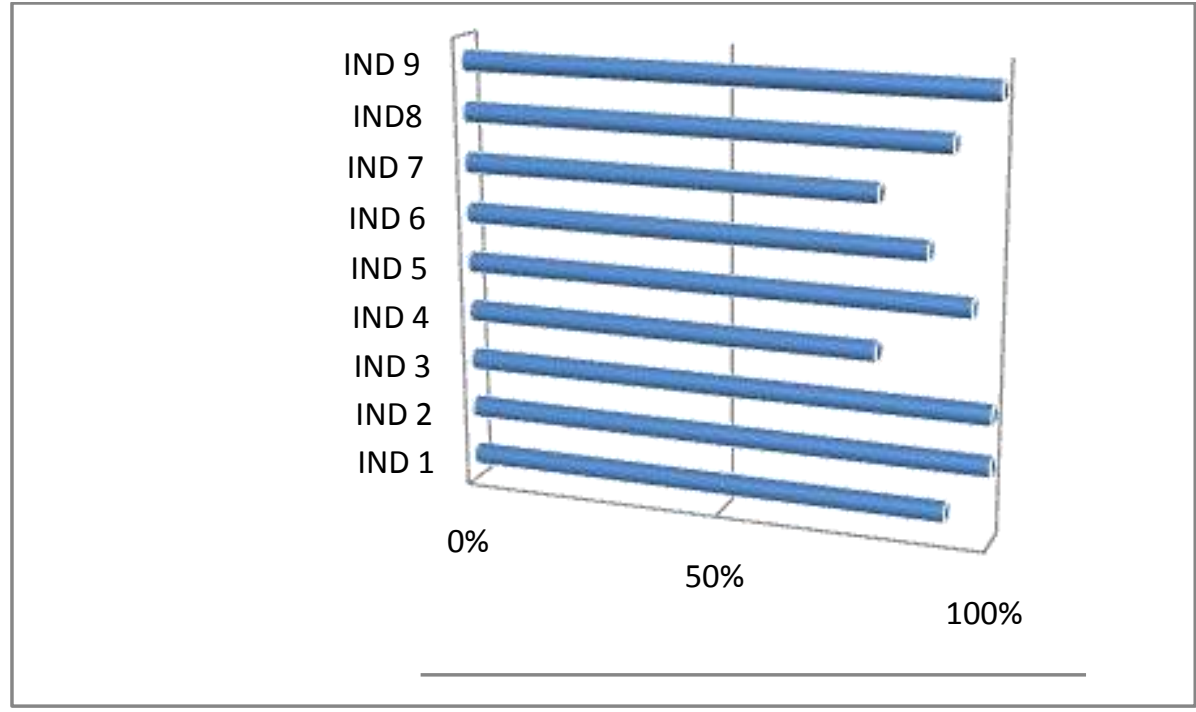

\section{Keterangan:}

IND-1: Judul; IND-2: Latar belakang; IND-3: Rumusan masalah; IND-4: Hipotesis; IND-5: Hasil pengamatan; IND-6: Analisis data; IND-7: Pembahasan; IND-8: Kesimpulan; dan IND-9: Rekomendasi

Setelah dilakukan perhitungan kinerja siswa, hal yang dilakukan selanjutnya adalah melakukan penilaian terhadap karya ilmiah siswa yang terdiri dari 9 kelompok. Karya ilmiah dikumpulkan satu pekan setelah praktikum dilaksanakan. Kemampuan siswa yang ditinjau dalam penelitian ini, terdiri dari 9 indikator, setiap kelompok melaksanakan ke-9 indikator tersebut dan berdasarkan hasil perhitungan diperoleh perbedaan persentase yang dicapai setiap kelompok dalam setiap indikator. Perbedaan perolehan rata-rata kemampuan siswa dalam setiap kelompok dapat dilihat pada Gambar 1. Pada Gambar 1 ditampilkan persentase ketercapaian kemampuan siswa dalam setiap indikator. Berdasarkan Gambar 1 dapat diketahui bahwa rata-rata kemampuan siswa dalam membuat karya ilmiah dari 9 indikator sebesar $91.78 \%$. 
Karya ilmiah tersebut diberi skor berdasarkan rubrik penilaian kualitas karya ilmiah. Rivers (2002) menyatakan bahwa pembuatan karya ilmiah membantu siswa untuk mengembangkan dan meningkatkan keterampilan berkomunikasi dalam bentuk tulisan. Karya ilmiah siswa yang ditinjau dalam penelitian ini, seperti dikemukakan di atas terdiri dari 9 indikator. Diantara sembilan kriteria kualitas karya ilmiah, kemampuan siswa tergolong sangat baik adalah dalam penulisan latar belakang, perumusan masalah, dan penulisan rekomendasi yang masing-masing memperoleh persentase maksimal yaitu $100 \%$.

Jika dianalisis dari judul secara keseluruhan telah ditulis dengan ringkas, dan telah sesuai dengan permasalahan dan tujuan. Judul seperti ini memperoleh skor yang lebih baik jika dibandingkan dengan hanya menyalin dari lembar kerja siswa (LKS) atau dari judul yang terdapat di surat kabar maupun internet. Namun jika dianalisis secara keseluruhan, persentase kemampuan siswa dalam menuliskan judul masih dalam kriteria sangat baik (92\%).

Penulisan hipotesis adalah hal yang penting dalam membuat karya ilmiah. Penulisan hipotesis yang jelas, akan memudahkan kita dalam melakukan percobaan. Rata-rata kemampuan siswa dalam menuliskan hipotesis berada dalam kategori baik dengan persentase $79 \%$. Hipotesis sebaiknya dapat dikembangkan secara tepat, dapat pula mengandung variabel yang dapat diuji akan tetapi tidak harus spesifik. Ada 2 kelompok yang menuliskan hipotesis dengan sangat baik. Hal ini disebabkan karena anggota dari kelompok tersebut melakukan diskusi kelompok. Hal yang didiskusikan adalah bagaimana seharusnya hipotesis tersebut disusun. Selain itu, tujuan dan rumusan permasalahan yang telah mereka tentukan sendiri telah dijadikan pedoman dalam pembuatan hipotesis.

\section{Simpulan}

Berdasarkan data hasil penelitian, pengolahan data, analisis dan pembahasan data maka dapat diperoleh kesimpulan bahwa karya ilmiah yang dibuat oleh kelompok siswa kelas VIII dalam mengatasi permasalahan lingkungan lokal memiliki rata-rata skor 2.8 dengan persentase $71.3 \%$, dan kriteria yang diperoleh adalah cukup baik. rata-rata kemampuan siswa dalam membuat karya ilmiah dari 9 indikator sebesar $91.78 \%$. 


\section{Saran}

Disarankan kepada peneliti selanjutnya untuk melakukan analisis penyebab kesukaran yang dialami oleh masing-masing siswa dalam mempresentasikan hasil karya ilmiahnya di depan kelas.

\section{DAFTAR PUSTAKA}

Arikunto, S. Prosedur Penelitian Suatu Pendekatan Praktek(Edisi Revisi VI).Jakarta: Rineka Cipta; 2006.

Cobern, W.W. \& Aikenhead. G.S. (1996). Culture Aspect of Learning Science. [Online]. Tersedia: http://wmich.edu/slcp/121.htm. [21 Desember 2011].

Fensham, P.J. (1994). The Content Of Science: A Constructivist Approach to it's Teaching \& Learning. Washington DC: The Falmer Press.

Pines \& West. (1986). Conceptual Understanding and Science Learning: an Interpretation of Research Within a Sources-of-Knowledge Framework. Science Education. 70(5), 583-604.

Rivers, D.B. (2002). Using A Course-Long Theme For Inquiry-Based Laboratories In A Comparative Physiology Course. Advance in Physiology Education. 26 (4), 317-326.

Suastra,I.W. (2005). Merekonstruksi Sains Asli (Indigenous Science) dalam Rangka mengembangkan Pendidikan Sains Berbasis Budaya Lokal di Sekolah: Studi Etnosains pada Masyarakat Penglipuran Bali. Disertasi PPs UPI. Tidak Dipublikasikan.

Suparno, P. (1997). Filsafat Konstruktivisme dalam Pendidikan. Yogyakarta: Kanisius (Anggota IKAPI). 